\title{
Pleuropulmonary Blastoma: A Single-center Case Series of 7 Patients
}

\author{
M Masood Sidiqi ${ }^{1}$, Ling $\mathrm{Xu}^{2}$, parshotam gera ${ }^{2}$, and Colin Kikiros ${ }^{2}$ \\ ${ }^{1}$ Royal Perth Hospital \\ ${ }^{2}$ Perth Children's Hospital
}

December 20, 2020

\begin{abstract}
Introduction Pleuropulmonary blastoma (PPB) is an aggressive primary neoplasm of pleuropulmonary mesenchyme occurring in children. Given its rarity, the International Pleuropulmonary Blastoma Registry (IPPBR) was established in 1988 to collect and assess data on PPB worldwide. We assessed the clinical characteristics, histopathology, genetic studies, management, and treatment outcomes of patients with PPB in our institution, and compared with the published literature. Materials and Methods We retrospectively reviewed the medical records of all PPB cases diagnosed at Princess Margaret Hospital for Children in Western Australia over a period of 26 years (1990-2016). Results Seven children (4 boys and 3 girls) were treated for PPB at a mean age of 11.5 months (ranges 1 month to 3.55 years). Histopathology showed type I PPB in five, type II in one, and type III in one. All seven patients underwent thoracotomy/lobectomy of the corresponding site. One patient required additional bladder resection for coexisting rhabdomyosarcoma. One patient was found to be positive for DICER1 gene mutation. Six patients received adjuvant chemotherapy with vincristine, adriamycin, cyclophosphamide (VAC) regime, with the mean duration of treatment for five patients being 9.4 months excluding one patient who deceased without completion of chemotherapy. During a mean follow-up time of 9 years, the overall survival rate for this cohort was $85.7 \%$ (6/7). Conclusions Our results are similar to those reported in the literature. It is crucial for clinicians to consider PPB in the evaluation of patients presenting with a cystic lung abnormality, especially in cases with DICER1 mutation or a strong family history of unusual cancers.
\end{abstract}

Pleuropulmonary Blastoma: A Single-center Case Series of 7 Patients M Masood Sidiqi MBBS, ${ }^{1}$ Ling Xu MBBS, ${ }^{1}$ Parshotam Gera FRACS MS MCh, ${ }^{1}$ Colin Kikiros FRACS ${ }^{1}$

1. Perth Children's Hospital, Department of Pediatric Surgery, Australia

\section{Corresponding Author}

Dr M Masood Sidiqi, Royal Perth Hospital, Perth, Australia

Tel: +61 452209094 E-mail: masood.sidiqi@health.wa.gov.au

\section{Full Contact details for each author}

Dr Ling Xu, Perth Children's Hospital, Perth, Western Australia, Australia Tel: 92242244 E-mail: lingx0322@gmail.com

Dr Parshotam Gera: Perth Children's Hospital, Perth, Western Australia, Australia, Tel: +61 419125486 E-mail: parshotam.gera@health.wa.gov.au

Dr Colin Kikiros: Perth Children's Hospital, Perth, Western Australia, Australia, Tel: +61 411477754

E-mail: colin.kikiros@health.wa.gov.au

\section{Conflict of interest}


The authors declare that they have no conflicts of interest regarding the publication of this paper.

\section{Hosted file}

MANUSCRIPT ppb - final.pdf available at https://authorea.com/users/383985/articles/499802pleuropulmonary-blastoma-a-single-center-case-series-of-7-patients

\section{Hosted file}

table 1.pdf available at https://authorea.com/users/383985/articles/499802-pleuropulmonaryblastoma-a-single-center-case-series-of-7-patients

\section{Hosted file}

table 2.pdf available at https://authorea.com/users/383985/articles/499802-pleuropulmonaryblastoma-a-single-center-case-series-of-7-patients

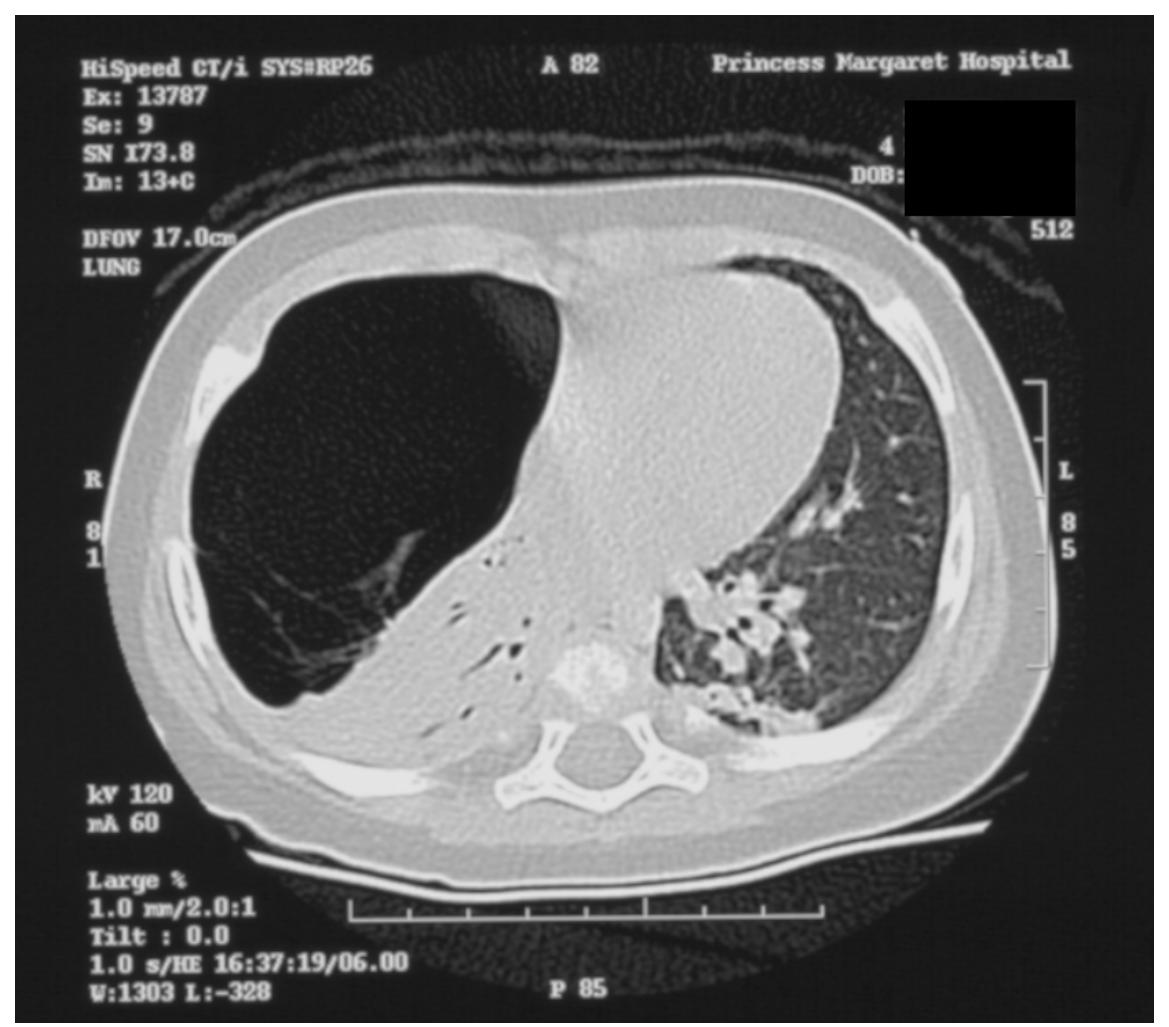

